\title{
The progressive Pentecostal conception of development within an African context of poverty
}

\author{
Kakwata, Frederick \\ North-West University \\ fkakwata@gmail.com
}

\begin{abstract}
This article, as literary study, is placed within the framework of a qualitative content analysis and deductive approach. It seeks to explore the progressive Pentecostal conception of development in a sub-Saharan African context of poverty. This investigation is based on ethnographic studies conducted in different parts of Africa. The study also aims to analyse the notion of evil spirits' work in relation to poverty and underdevelopment. These notions are raised by the new conception of development. It is argued that Western development theories implemented in Africa failed miserably to clarify the problem of poverty and underdevelopment. In the midst of crises and despair, a new trend of Pentecostalism emerged that promotes a completely new conception of development, which has a spiritual focus. The latter resonates strongly with the African worldview, reflects the biblical truth, and demonstrates that the ultimate cause of poverty is fundamentally spiritual, which implies the solution should be similar. Therefore, recent studies reveal that the movement has had more success in addressing poverty than the strategies of NGOs. However, this success is limited to an individual level. This means the structural problem responsible for the impoverishment of the masses in Africa is not dealt with directly. In this regard, an all-inclusive focus is needed that could pave the way to sustainable social and economic change in Africa.
\end{abstract}

Key words

Progressive Pentecostal; development; poverty; Africa; spirituality; spiritual warfare

\section{Introduction}

This article is concerned with the progressive Pentecostal conception of development. Africa has lagged behind in its development as compared to other continents. Speaking of Africa, means mentioning poverty and underdevelopment. Africa's current state of under-development and poverty historically has an extended path. It stretches from the period 
of the slave trade, to the legacy of colonization, through the dictatorship regimes, to neo-colonialism and current challenges of globalisation (Kakwata 2014:229). In this regard, Haynes (2008:8) points out that most sub-Saharan countries have not joined the ranks of developed nations. On the other hand, certain countries of East and South Asia (e.g. South Korea and Taiwan) that went through the same process of decolonisation, have experienced extraordinary developmental advance through sustainable economic growth.

Development is a concept that is hard to define accurately. From the perspective of economy, development is often understood as 'structural change and improvements within community systems encompassing both economic change and the functioning of institutions and organisations' (Phillips \& Pittman 2009:9). The idea of change relates to the process of transformation. In turn, this process implies change of the whole person. This includes the material, social and spiritual dimensions as well as the community, economics, social and political contexts (Winter \& Hawthorne, 1999: 588).

Development, therefore, can be viewed as a tool or instrument through which poverty can be alleviated, whereas underdevelopment entails the opposite scenario. The conditions of poverty and underdevelopment provided a fertile ground for Pentecostalism to flourish within African society, as was pointed out by Togarasei (2011:336).

Naturally, there are different expressions of Pentecostalism. However, this article focuses explicitly on a new emerging element of the movement that missiologists label progressive Pentecostalism. Miller and Yamamori (2007:2) define this movement as 'Christians who claim to be inspired by the Holy Spirit and the life of Jesus and seek to holistically address the spiritual, physical, and social needs of people in their community'. This particular brand of Pentecostalism is intriguing in that it promotes a conception of development which is completely different 'from both the mainstream development and more radical post-development views'1 (Freeman, 2012:9).

1 Post-development theory emerged in the late 1980s and early 1990s in developing countries. This was due to the increasing disappointment with the development efforts and practices, which Africans considered as Western- oriented and -motivated (Berg, 2007:541-544). 
In this regard, progressive Pentecostals understand development as a war against spiritual forces (devil and demons) and not a fight against human rights violations, oppressive, exploitative and unjust political systems, or social structures, as mainline Evangelical, or Catholic development agencies advocate (Myers 2015:116).

In light of the exposition above, this article essentially reports on a literature review that explores the progressive Pentecostal conception of development within the sub-Saharan Africa context of poverty. This review examined the ethnographic studies by different scholars conducted in several parts of Africa. The focus was on the research of Dena Freeman, anthropologist at the London School of Economics, and Martin Lindhardt, associate professor of cultural sociology at the University of Southern Denmark. The present study sought a practical insight into the transformative framework espoused by the progressive Pentecostal movement (to be expounded below). The study also analysed the notion of evil spirits' work in relation to poverty and underdevelopment, and how this motive links with biblical theology.

\section{Progressive Pentecostal movement}

In recent years, global Christianity has experienced the emergence of a new version of Pentecostalism, which certain missiologists consider as the third wave $^{2}$ of the charismatic $3 /$ Pentecostal movement, or the neo-Pentecostal focus termed 'progressive Pentecostalism' (Myers 2015:115). According to Freeman (2012:10), this movement emerged from the impoverished urban slums of sub-Saharan Africa and other parts of the global south such as Latin America and parts of Asia. The mentioned spiritual movement has

2 The first wave is the classical Pentecostalism that emerged from the Azuza Street spiritual revival movement of 1906 in the USA, it expanded to Europe, thereafter to Africa. The second wave of Pentecostalism is the charismatic movement that developed in the 1960s within mainstream Christian denominations such as the Roman Catholics, Anglicans, Lutherans, and Presbyterians (Freeman, 2012:11).

3 The concept 'charismatic' denotes a movement of Pentecostal spirit that emerged in several Roman Catholic and Protestant churches during the 1960s and 1970s (Miller \& Yamamori, 2007:18). Missiologists labelled this phenomenon as pentecostalisation of mainstream Christianity, seeing that certain members within these churches 'began to experience the gifts of the Holy Spirit in the form of speaking in tongues, spiritual healing, miracles and the like' (Freeman, 2012:11). 
impacted Christianity deeply and has become the fastest growing Christian movement on the African continent.

Freeman (2012:2) observes that for the past three decades, Africa has experienced an explosion which has altered its religious landscape drastically when millions of people joined Pentecostal churches. It is estimated that in South Africa alone, one third of the professed Christians (i.e. 12.5 million South Africans) are members of these non-traditional churches. Their numbers are increasing rapidly compared to those of traditional churches that remain static or even decline (Attanasi \& Yong 2012:67). Thus, Pentecostalism is becoming the dominant form of Christianity in the contemporary African setting (Anderson 2004:103). Lindhardt (2015:1) holds the same view and explains that from an initially isolated movement, Pentecostalism in recent decades has become a force to be considered within African Christianity and sub-Saharan African societies in general. This is probably because, as Miller (2009:278) indicates, Pentecostalism was born amongst the poor, which suggests that this movement links itself to the needs of the destitute. Progressive Pentecostalism emerged during the period from the 1980 s to the 1990s, alongside classical Pentecostal, ${ }^{4}$ charismatic and neo-charismatic ${ }^{5}$ churches.

Miller (2009:280) defines progressive Pentecostals as, 'Christians who, inspired by the Holy Spirit and the life of Jesus, seek to address holistically the spiritual, physical, and social needs of people in their community.' Currently, various Pentecostal trends are flourishing in Africa, however, for the purpose of this article, special attention is given to progressive Pentecostalism. The latter rose to prominence at the time when most African

4 The term classical Pentecostalism refers to a movement that developed from early American and European Pentecostal churches as a result of the spiritual revival that took place 'at 312 Azusa Street in Los Angeles California on the 9 April 1906' (Burgess, McGee \& Alexander, 1989:3). Classical Pentecostals emphasise 'the importance of speaking in tongues or glossolalia, as evidence of the baptism by the Holy Spirit' (Freeman, 2012: 10). Examples are the Assemblies of God, ELIM Church, Church of God, or the Apostolic Faith Church (Kakwata 2014:16).

5 Neo-charismatic/neo-Pentecostal movement, also called the third wave of Pentecostalism, indicate 'Pentecostal renewal phenomena associated with transdenominational fellowships, prayer groups, ministries and independent churches, which came into existence or prominence from about the last three decades of the twentieth century' (Asamoah-Gyadu, 2005:26). 
nations were experiencing a dramatic decline in economic growth from the mid-1970s, which worsened in the mid-1980s (Babatunde 2012:142).

Having briefly described the progressive Pentecostal movement, the following section will provide a synopsis of development within Africa.

\section{Perspectives on African development}

The period that followed the movement to independence in Africa during the 1950s and 1960s, led to expectations and high hopes of progress and development within the new political climate of these African states. Various policies and strategies were implemented to achieve rapid and sustainable socio-economic development in the least developed countries. Freeman (2012:3-4) explains that in the 1970s, most African nations concerned with development in their societies accepted loans from the World Bank and International Monetary Fund (IMF) to finance large infrastructure projects. However, he points out that in the 1980s, the oil price increased, which was followed by the rise of inflation and the decline in commodity prices. Consequently, these loans degenerated into large debts that compromised several economies in Africa. To overcome this deficiency, the World Bank and IMF implemented the structural adjustment policy. This policy consisted mainly of liberalising trade with the goal of 'boosting exports in order to gain the foreign exchange needed to repay the external debt' (Dembele 2012:184). This also entailed reducing public expenditure, privatising extensive government businesses and services, devaluing the currency and scaling down the regulation of businesses (Myers 2015:115).

From the exposition, above, it is evident that the implementation of the development theories which Western theorists adopted for Africa, were in crisis, particularly within the sub-Saharan region. These theories failed miserably to clear up the problem of underdevelopment (Himmelstran 1994:37), and 'help Africa to build strong, independent, self-sustaining economies' (Amaizo 2012:137). It became clear that in the postindependence era, most African nations experienced a gradual decline in their economy, until it reached the level which Rodney (2012:6) describes as 'complete stagnation'. However, as Amaizo (2012:6) argues, the opposite could have happened, given the abundant natural resources the continent has at its disposal and the low cost of labour. 
In this regard, Babatunde (2012:141-172) in his article, 'Africa's growth and development strategies: a critical review', concludes that the structure of the economy implemented in most African countries at the dawn of their independence was not intended to stimulate sustainable domestic growth, but rather to serve the economies of the former colonial powers. Amaizo (2012:121) concurs that the objective of the former colonizers after independence was merely to transfer minimum control of politics to the autochthones (i.e. indigenous inhabitants), but still maintain the colonialist economy as a form of neo-colonialism. One of the most striking examples he mentions, is the way in which the French treasury controls the reserves of ex-French colonies of West-Africa who are using the $\mathrm{CFA}^{6}$ as legal tender.

He explains that according to the post-colonial pact, these countries have to deposit $50 \%$ (previously 65\%) of their reserves to the French Treasury with a $20 \%$ investment liability paid as well. Moreover, the currency issued by the Central Bank of these nations is not printed locally but in France. This clearly indicates the continuing dependency of ex-French colonies on France. Similar situations are also reported for French colonies of Central Africa, the ex-Portuguese territories and ex-British colonies (Amaizo 2012:127). To solve this problem, Amaizo (2012:137) advocates a new approach to development for Africa, which he labels alternatively 'developmentalism', entailing:

- Severing the links African nations maintain with their exmetropolises.

- Investing heavily in human capital by changing the inherited Western-oriented educational systems.

- Achieving intellectual autonomy to solve Africa's pressing problems from an Africa-centred point of view.

However, Babatunde (2012:172) specifies that attempts to restructure African economies have failed miserably in stimulating growth. In certain cases, the restructuring had engendered conflicts, which stifled the countries' development.

6 Communauté Financière de l'Afrique (Financial Community of Africa). 
Consequently, the continent has been ravaged by various afflictions amongst which were massive unemployment, underemployment and low wages, to mention a few. This situation has caused discontent and frustration amongst the population. In recent years, it led to an unprecedented migration of Africans of working age to the Western world in the hunt for improved job opportunities (Amaizo 2012:119). Kalu (2010:168) describes the irony in this migration: during the era of the slave trade, Africans were displaced forcefully from their land to be enslaved in the West, but nowadays Africans are risking their lives to cross the Mediterranean Sea in search of better opportunities in Europe - where they are unwelcome. However, the West does share in the responsibility for the current situation of underdevelopment and poverty Africa is experiencing. In a sense, as Pogge (2004:23) asserts, the West is using its 'economic, technological, and military advantages to impose a global institutional order that is manifestly and grievously unjust.'

In such an environment of socio-economic crises and despair, a new trend of Pentecostalism took root. The same period that Freeman (2012:510) narrates, has also witnessed the rise of several non-governmental organisations (NGOs). For example, in Kenya, the number of NGOs increased from 511 in 1996 to 2511 in 2003; in Tanzania, it rose from 20 in the early 1980s to 3000 in the 2000s; and in Ethiopia it increased from 60 at the end of 1980s, to nearly 2000 in 2007 . He indicates that numerous scholars and Pentecostal leaders believe that the worsening economic condition and a desperate situation in the developing world triggered the continuing growth of the new trend, which manifested in the Pentecostal movement.

There have been extensive discussions on poverty and underdevelopment and its roots in Africa. The direst issue at present is why poverty persists in sub-Saharan Africa amid a world of apparent abundance. As will be discussed later, the answer to this question will help explain the root cause of poverty, which is viewed as fundamentally spiritual (Myers 2007:88). This requires a new focus on development, and redirecting the development debate towards the spiritual realm, given that problems encountered in society have a spiritual dimension. This presupposition provided a basis for the present study. 
After the brief overview of African development, the following section shifts the attention to progressive Pentecostals' conception of development.

\section{Progressive Pentecostal conception of development revisited}

Several ethnographic studies have been conducted throughout Africa by different scholars focusing on Pentecostalism (Freeman, 2012; Lindhardt, 2015; Miller \& Yamamori 2007). These studies reveal that in the past 30 years, Africa has experienced a massive explosion of Pentecostalism, which radically changed the religious landscape and attracted millions of adherents. In summary, these studies reveal two main characteristics of progressive Pentecostalism:

First of all, Dena Freeman (2012:2) finds that this movement does not separate religion from development. Furthermore, for the most part, progressive Pentecostalism does not draw developmental divisions as is the case with faith-based organisations $(\mathrm{FBOs})^{7}$, but rather promote a completely different conception of development. This understanding emphasises the betterment of humanity in line with the interests of the poor whom they serve. However, this approach is in stark contrast with that of the NGOs (Myers, 2015:118). As was mentioned, Freeman (2012:9) labels progressive Pentecostalism as the third approach to development. ${ }^{8}$ According to this stance, development is not viewed as a fight against unjust social structures or human right violations, as contemporary Evangelicals and NGOs posit (Bragg, 1987:41-42). Instead, Progressive Pentecostalists focus on:

7 Faith-based organisation.

8 Most development theories were formulated after the Second World War, the period characterised by the rise of the capitalist system and the evolution of the industry (Coetzee 2001:27), which also can be considered as the first or classical approach to development. The second approach is the post-development theory, which emerged in the late 1980s and early 1990s in developing countries due to the increasing disappointment with the 'Westernised' development efforts and practices (Berg, 2007:541-544). For that reason, the theory advocates alternatives to development by providing 'ways of thinking about social change beyond Eurocentric development discourse and engages with the strategies of those excluded by the Western model of development. By confronting the flaws of post-development' (Ziai 2007:iv). 
What God wants for Africa and most recently in terms of the gospel of prosperity. A continent blessed with health, wealth and abundance, where people work hard, pray hard and live upright moral lives ... what the devil wants for Africa, however is underdevelopment, poverty and suffering (Freeman 2012:2).

Thus, for progressive Pentecostals, poverty is attributed to the work of the devil; it is also described as a spirit, a disease, an anomaly from which Christians must strive to get rid of through deliverance (Togarasei, 2011:340). In this regard, development requires spiritual warfare or a fight against witchcraft. In other words, as Freeman (2012:2) specifies, development entails spiritual warfare ${ }^{9}$ that counters evil (the devil and its demons), and its affliction on human life. He also indicates that this notion has been received with increased enthusiasm amongst African Pentecostals, contrary to the socio-economic rhetoric of international NGOs.

After establishing the spiritual base, subsequently the focus is on the work of evil spirits within an African context of poverty relationships.

\section{The work of evil spirits in poverty relationships}

This section examines the progressive Pentecostal notion of ways in which evil spirits are involved in poverty. The analysis focuses on several identified strategies that evil forces allegedly use to exercise dominance and control over people. The aim is to demonstrate that the ultimate cause of poverty is fundamentally spiritual. Christian (1999:149), in his study on 'principalities, powers and poverty', acknowledges that poverty is not necessarily the consequence of the fall of the human race, but may also be the result of satanic activities. Myers (2007:87) has established that poverty is the result of flawed relationships between people, or between individuals and God - which portrays a lack of love. However, in a poverty-related context, the virtue of love is the key factor that maintains sound relationships between human beings and God, and amongst people mutually.

9 'In general, the term spiritual warfare refers to the fact that Christians are involved in the struggle between the forces of God and those of evil ... it is a way of characterizing our common struggle as Christians' (Erickson, 2013: 869). This focus is prevalent in progressive Pentecostal activities within Africa. 
As Christian (1999:149-150) points out, the lack of love can be seen in the terror of war, financial exploitation, racial discrimination, and abject poverty. He understands this condition as the domination and the influence of the devil and its forces on people, social organisations and structures. Christian identifies six areas of the devil's influence within the context of poverty relationship levels. These areas are: mind, health, habits, relationships, exploitation of curses, will and identity, a focus which concurs with the progressive Pentecostal conception of development as discussed below. The mentioned areas are categorised and discussed below.

\section{Evil spirits and individuals in poverty relationships}

There are certain areas where evil spirits impact relationships of poverty. These are expounded below.

\section{The mind}

The mind is an area which the devil attacks most often. Christian (1999:151) asserts that evil forces affect the mind of people, particularly the unbelievers, at the level of their belief system. He argues that these forces blind the minds of people (2 Cor 4:4) from the truth. This causes the poor to believe in a false identity (defined by race or place in life), or offers an alternative interpretation for life's experience contrary to God's intention.

The aim of progressive Pentecostalism seems to be addressing the issue of the belief system in the context of poverty since this system blinds unbelievers' minds from the truth. Togarasei (2011:347) observes that the progressive Pentecostals' most important contribution to alleviate poverty was the positive mind-set it facilitated in believers. In the same vein, Asamoah-Gyadu (2005:404) argues that Pentecostalism addresses the structures of oppression that place Africa in a situation of 'backwardness, mediocrity, and non-achievement'. He also specifies that through motivational messages, 'African Pentecostalism has initiated a move from Afro-pessimism to Afro-optimism and hope'. In this context, Freeman (2012:2) points out that progressive Pentecostals understand development in terms of 'what God wants for Africa, a continent blessed with health, wealth and abundance, where people work hard, pray hard and live upright 
moral lives. What the devil wants for Africa, however, is underdevelopment, poverty and suffering'.

From the discussion above, it can be inferred that Africans have emerged from a history of slavery and colonialism, which cause them to lose their sense of humanity. For that reason, there is a need of motivating messages from progressive Pentecostals that inspire people to believe in themselves again. Such messages can change people and their stories, correct moral conduct, give a new meaning to human life, and provide a vision and hope for the future (Myers, 2015:118). This will help clear up the roots of belief systems that blind the poor to the truth and keep them enslaved and deceived.

\section{Health}

The evil forces also can influence people's health - several biblical texts attest to this situation. For example, Matthew 9:32-33 reports the story of a dumb man who was possessed by a demon and could speak again after Jesus had cast out the demon. Luke 13:10-16 also records that a woman was bound for 18 long years to a sickness caused by a spirit. She was released from that illness after Jesus had laid his hands on her. Evidently, according to this view, there are diseases that originate from demons, therefore, the healing also necessitates prayer and exorcism.

In a previous study ${ }^{10}$ on the concepts of witchcraft and poverty, the researcher had drawn attention to the incidence of a witch who impoverished someone by inflicting a disease that incapacitated the person to work and earn money. The Millennium Development Goals (MDGs) ${ }^{11}$ also recognise health as an important factor that contributes to the reduction of poverty and helps ensure welfare. Therefore, the international community was committed to combat diseases such as HIV/Aids, malaria and other syndromes that affect the poor (Singh, Gonzalez \& Thomson, 2013:20). This is part of the overall strategy to eradicate poverty.

10 'Witchcraft and poverty: A pastoral perspective' (unpublished article).

11 As will be indicated later in this article, these goals have been replaced by the UN's SDGs - Sustainable Development Goals for 2030. 
Progressive Pentecostalists understand this reality and, therefore, pay considerable attention to spiritual healing, which is one of the key characteristics of this movement. Freeman (2012:13) states that healing may be mediated through prayer or the laying on of hands in the name of Jesus. In this movement, illness is often connected to demonic possession, as is the case with poverty (Togarasei, 2011:341). Therefore, these conditions require exorcism and spiritual warfare for healing. The truth is that not every sickness is caused by demons. However, given the poor condition of healthcare systems in several African countries, progressive Pentecostalism has attracted a large membership due to its focus on supernatural healing services.

\section{Relationships}

In the context of poverty, as Christian (1999:152) points out, relationships constitute another area in which the devil and its evil forces make an impact. This is done by strengthening divisive forces and creating the new ones; sowing seeds of enmity between people; and keeping the poor marginalised in society. In contrast, Christian states that relationships have been designed to serve as positive agents in individuals' path to becoming what God wants them to be. This is because humans are relational beings, created in God's image to enjoy fellowship with God, others, and nature. These interrelations are based on love, which entails sharing and caring. Sin is the harmful element that destroys the image of God in humans and breaks the mentioned basic relationships. These broken relationships portray the lack of love, which means sin is synonymous with lovelessness (this condition is evident in unjust, exploitative and oppressive structures). Thereby, the absence of this Christian relational dynamic is one of the reasons why poverty gains a foothold in society (Kakwata 2016:1).

Erickson (2013:518) also indicates that sin is a relational concept, which denotes deliberate ignorance of God's will, error and inattention to the Law of God, and thus impacts poverty. He identifies three causes that lead to error. Humans can mislead their fellow human beings, people can deceive themselves and evil spirits can hoodwink people. This is why Christian (1999:150) maintains that evil forces can influence people in any situation with the goal 'to separate them from the love of God'. 
Pentecostals take the issue of sin seriously and offer deliverance from this condition, (Freeman 2012:24). According to Miller and Yamamori (2007:33), this gives Pentecostals an economic advantage over other believers, because of the movement's prohibition targeting alcohol, cigarette, gambling and womanising. Thus, they maintain that by proscribing these social evils including premarital sex, Pentecostals contribute to a sound education, especially for young women. In addition, Pentecostals consider the issue of sin and lacking to sow the seeds of prosperity through tithes and offerings, as an impediment to development.

There is a deep controversy surrounding the issue of tithing. Among Evangelicals the views are divided. Some argue that Christians are under the obligation to give tithes. Failing to do so implies a breach of the covenant and attracts poverty to individuals' lives. In this regard, proponents rely on Malachi 3:6-10 to justify their position. Others oppose tithing under the pretext that it is bound to Mosaic Law, and is, therefore, irrelevant under the new covenant. Tithing is explained sufficiently in the Old Testament, but, the New Testament does not place such strong emphasis on this issue. As a matter of fact, there is no evidence of the discontinuity of tithing in the New Testament testimony. Nevertheless, it can be stated that, just as faithfulness in tithing brought blessings in the Old Testament, it also can attract benedictions to the lives of believers under the new dispensation. However, it should be noted that tithing alone does not fulfil the necessary requirements to receive God's blessings. For example, the New Testament reveals that blessing is fundamentally spiritual (Eph 1:3) and stems primarily from a personal communion with God.

\section{Curses}

An interesting notion within the context of poverty relationships is presented by Christian (1999:153), who postulates that 'the devil also exploits the curses that people cast on each other'. Asante and Mazama (2009:188189), leading figures in the field of African-American studies, provide valuable insight on the impact of curses in Africa. They explain a curse as any attempt to use an invocation or utterance to cause someone harm. Kalu (2008:177) elucidates that curses could be targeted on individuals and families by envious or wicked people, or by witches. According to Okpara (2016:5) 'such negative declarations have supernatural powers to produce 
destructive effects in someone's life, or cause harm and pain to people in health, business, and relationship'. Curses also have the capacity to enforce invisible limitations onto someone's life to such an extent that the person strives hard, but reach limited results.

Asante and Mazama (2009:188-189) posit that the idea of humans having curses placed on them, as indicated above, is highly prevalent in Africa. Unlike believers from the Evangelicals, who either fail to address, or completely ignore the issue of generation curses, African progressive Pentecostalism's worldview considers this phenomenon. In a previous study on witchcraft and poverty, the researcher emphasised that the issue of generational curses is extremely controversial amongst Evangelicals. Certain scholars, such as Martin, Rische and Van Golden (2008:633), oppose the idea of generational curses claiming that it has no biblical foundation. They argue that the alleged passage referring to these curses in Jeremiah 32:18-19, does not apply to Christians. However, Rallo (2000:xi) in Breaking Generational Curses and Pulling Down Strongholds, acknowledges the reality of hereditary bondages in humans or family lines, and describes these as 'dangerous snares, traps, and pitfalls that plague millions of people around the world'.

The Old Testament narratives record numerous instances that demonstrate this reality. For example, Ham, the father of Canaan, saw his father, Noah, naked, but the curse was passed directly on to Noah's grandson (rather than his son, Gen 9:18). Furthermore, the Lord warned Israelites against the penalties for their disobedience (Lev 26:38-39) by saying:

You will perish amongst the nations, and your enemies land will consume you. So, those of you who may be left will rot away because of their iniquity in the lands of your enemies; and also because of the iniquities of their forefathers they will rot away with them (NASB). ${ }^{12}$

According to the wilderness narrative, Achan's sin of covetousness brought calamity on the whole nation of Israel (Jos 7:21).

The New Testament is not as explicit on the issue of generational curses. For example, in John 9, the disciples asked Jesus if the blind man they

12 New American Standard Bible. 
encountered was in that state because of his, or the sins of his parents. Jesus replied that it was not because of the sin of his parents nor his own, but rather to reveal the glory of God. Asamoah-Gyadu (2004:402-403) understands this Scripture as repudiating the notion of generational curses in the new dispensation, as the case is in Ezekiel 18:1-4. However, a closer examination of the context of this verse, gives no evidence that Jesus did overrule the idea of generation curses. He merely referred to a particular case in which the blindness did not result from the parents' sins.

In an African worldview, as Asamoah-Gyadu (2004:405) points out, the effects of generational/ancestral curses can be perceived in 'the prevalence of chronic and hereditary diseases, emotional excesses and allergies, and frequent miscarriages and deaths, suicidal tendencies, and persistent poverty within one's family'. He adds that in such cases, progressive Pentecostals advice the victims to confess personal and forefathers' known/ unknown sins. They advocate that sufferers should break with ancestral ties and ceremonies in which the victims took part wilfully, or the extended family performed on their behalf. Believers also are urged to invoke the reversal of curses through the name of Jesus, as well as his blood and the power of the Holy Spirit (Kalu 2008:182).

The theme of generational curses has become important and requires continual research among scholars in theology. This should involve studying this phenomenon in its full complexity.

\section{Will}

The will, as Christian (1999:153) indicates, is the domain where evil forces attack and influence the poor as well as the non-poor. He argues that the purpose is to influence the different choices people may make throughout their lives, to control the poor's perception of their future, and ultimately to destroy the hope of the poor for a better future. Bragg (1987:41) asserts that 'transformation ${ }^{13}$ is hope', in the sense that if there is no attitude of expectation or optimism, and if pessimism is rooted in the culture and tradition, positive social change will be difficult.

13 Samuel and Sugden (1987:40) make it clear that the concept of transformation in this context, is not an alternative development strategy; it rather stands for a Christian framework as basis for a new perspective on human and social change. 
In the midst of poverty, suffering, injustice, pain and despair, the message of progressive Pentecostalism (about what God wants for Africa) is well received. It replaces pessimism with hope by addressing the real needs of Africans and raises expectations that they may prosper. It has been proven that in poor countries, desperate people overwhelmed by their suffering, turn to religion with the hope of having their needs met. In this regard, the Gospel implying good news to the poor, produces hope for the future. The psalmist also considers hope as a comfort in times of affliction (Ps 119:49-50). Hope is, therefore, one of the characteristics of transformation without which change becomes difficult.

As noted previously, the modernisation theory raised the hope that all people would enjoy prosperity since Third World nations underwent a process of transition from a traditional society to a modern one. The modernists were also confident that extreme poverty and hunger would be reduced by half by the year 2015. They considered the Millennium Development Goals (MDGs) as a blueprint for the transformation of human conditions (Sachs 2005: xi). Currently, the MDGs have been replaced by the Sustainable Development Goals (SDGs). Reality has proven that the hopes these approaches awoke in the masses were unrealistic.

Nevertheless, recent studies reveal that progressive Pentecostalism holds the most realistic hope for Africans which has a directly positive effect on victims of poverty. In the same vein, Tagarasei (2011:350) postulates that through their message, progressive Pentecostals initiate a movement from Afro-pessimism to Afro-optimism and hope. He further asserts that this attitude is highly necessary if Africans are to deal with poverty successfully.

\section{Identity}

The evil one and its demons are also believed to attack the identity of people in relationships of poverty. In this regard, Christian (1999:153) suggests that evils spirits deceive the poor to believe that they are not made into the image of God. In this, way he argues, the poor feel non-existent, valueless, and humiliated. They even are led to believe that they are uninformed, ignorant people with no knowledge. They have the perception that God has forsaken them and they have no resources with which to contribute to the community. This lack of self-confidence and hopelessness is the result of what Myers (2015:117) terms 'marred identity', which leads to the 
powerlessness of the poor. He affirms that it is difficult to address the issue of powerlessness and recover the true identity when working with the poor and the oppressed. Furthermore, he explains: progressive Pentecostals understand that the poor's true identity is affirmed through the visitation by the Spirit's baptism, as well as healings, deliverances, prophecies and miracles.

Freeman (2012:13) also points out that numerous impoverished people, particularly those in the urban areas, turn to Pentecostal churches in their miserable, despised and hopeless state. They feel powerless to change their unfortunate situation. He specifies that through their involvement in the church with pastors and other church members, in Bible study, prayer and healing, the poor can begin to view themselves as valued individuals who form part of the family of the people of God, as somebody rather than nobody. Therefore, commenting on ethnographic studies conducted in different parts of Africa on Pentecostalism, Myers (2015:117) concludes that 'the Pentecostal worship and its sense of new community can be an antidote to marred identity'.

After examining the various areas of the devil's influence within the context of poverty relationships, the following section focuses on the role demonic forces play in social structures.

\section{The role of demonic forces in relation to social structures}

In the context of poverty relationships, Christian (1999:154-156) posits that evil spirits do not only influence the persons implicated in such relationships. These spirits also impact the social structure itself as the system within which these relationships operate. He suggests that evil forces exert their influence on economic, social and political structures as well as social systems, cultural norms and group habits - through people. In his book, Transforming Society, Maggay (1994:82) alludes to this condition when he describes social action not as a fight against flesh and blood, or simply the dismantling of unjust social systems. According to him, this rather entails a battle with the evil forces in their cosmic and social dimensions. He insists that an effective initiation of social transformation depends primarily on identifying demonic forces entrenched in a given social structure, whether it is a spirit of injustice, indiscipline, futility, racism, multinationalism, or 
debt. Erickson (2013:869) also acknowledges the impact that evil spirits have on humans (i.e., influencing their thoughts, demon possession, or inflicting illnesses), but also social and political institutions. He explains that the task of Christians is to discern the activity of these evil forces, to arm themselves, and resist these forces by engaging in spiritual warfare.

This notion is in accordance with the progressive Pentecostalists' understanding of the threat evil forces pose to humans in daily life. In this regard, for progressive Pentecostalists, development implies waging war against evil forces. This approach is contrary to that of NGOs and international agencies, who frame development as a war against poverty or unjust social structures (Freeman, 2012:2). The mentioned Pentecostal movement focuses explicitly on the transformation of individual subjects, which seems to have been more effective in bringing about social and economic change. In this context, Freeman (2012:25) makes the following observation:

Converts learn to see themselves and their lives in a new light. They reject passive, fatalistic beliefs and reclaim their agency. And in very many cases this new sense of empowerment leads to new behaviours and new types of social relations - both of which enhance economic development and foster upward social mobility.

Thus, personal transformation as the focus of progressive Pentecostalism, is an important factor in social transformation. The mentioned movement understands the cause of poverty as fundamentally spiritual, as is attested by several studies on this theme. Therefore, they seek to transform individuals' subjective demeanours in order to bring about social change.

It is worth mentioning that the spiritual focus of Pentecostals does not imply that the movement does not engage in any development projects whatsoever. Rather, progressive Pentecostals view the cause of poverty as fundamentally spiritual, therefore the solution should be similar. Recent studies indicate that social activities from an integral part of the life of progressive Pentecostalism. Some of these churches are engaged in mercy ministries (providing food, clothing, shelter); others in counselling services (addressing addiction, divorce, depression), and still others in education (providing day care, schools, tuition assistance), et cetera. Myers (2015:115) also acknowledges that this type of social involvement is partly the result 
of the Spirit's empowerment, as was the case in the Spirit-filled community of the early church.

In light of the discussion above, it is necessary to propose a structural corrective that can remedy weaknesses in the Pentecostal movement's approach to the issue of poverty.

\section{Structural corrective proposed}

Different scholars believe that personal transformation, which is the focus of progressive Pentecostalism, is a necessary foundation to bring about sustainable social and economic change in Africa. However, this approach is insufficient to sustain the mitigation or alleviation of poverty that is entrenched in the socio-economic structures of the African society. This entails aspects such as 'economic exploitation, corruption, illiteracy and unfair international trade practices that have contributed to creating misery and poverty in Africa' (Asamoah-Gyadu 2004:398). The progressive Pentecostalists do not directly address the spiritual dimension of poverty, which is engrained in the larger structure. This undermines the apparent success of a spiritual approach to poverty alleviation. This can be pointed out as a clear weakness of the progressive movement. Togarasei (2011:14) also points out its political irrelevance that prevents the movement to impact the sinful social structures. As corrective, he advocates social justice and to challenge and demolish the 'powers' that hold such deep destructive sway over entire societies. This is a necessary prophetic voice on the part of Pentecostals, and can help eliminate poverty on the continent.

Before tackling poverty, it should, however, be remembered: this social ill has many facets and manifests itself at different stages, at individual, collective or societal level. However, the cause of poverty, as Myers (2007:88) emphasises, is fundamentally spiritual. Scholars and development practitioners conducted deep-set studies on the causes of poverty and underdevelopment in sub-Saharan Africa, which is one of the regions of the world where 'extreme poverty is now heavily concentrated' (Sen, 1999:99). Nevertheless, these scholars did not understand the root cause of poverty in terms of the spiritual dimension. 
On the other hand, there is a growing criticism that progressive Pentecostals spiritualise poverty and the underdevelopment Africa is experiencing. They are critiqued for their tendency to search for explanations and interventions in the esoteric religious, and abstract theological realms (Asamoah-Gyadu 2004:399). Degbe (2014:245) refers to this tendency as a continuity of traditional religious beliefs or its worldview. This criticism may be true to a certain extent and reveals aspects of exaggeration in the movement. It also portrays the weakness of the progressive Pentecostalism since most leaders in this movement did not receive solid theological training that would allow them to deal effectively with traditional religious realities. Nevertheless, research shows that the Pentecostal conception of development is practical, resonates powerfully with the African worldview, and addresses the problems that occur in the African setting, which portrays the reality of the world in which inhabitants are living.

However, Progressive Pentecostalism does have a deficiency. The adherents rarely take into consideration the evil that is rooted in structures and which contributes to the ongoing cycle of poverty. Thus, if poverty is to be eradicated, a comprehensive approach is needed. In this regard, Maggay's (1994:82) approach to structural causes of poverty as outlined above, can inspire progressive Pentecostals to address poverty at the societal and structural level. As was pointed out previously, people are being impoverished at different levels of society. Progressive Pentecostals with their spiritual focus, if they address poverty at societal level, can point the way to alleviate this condition. This is because, as argued above, the core causes of poverty and underdevelopment in Africa can be relayed to the spiritual realm. But the progressive Pentecostals do not tend to answer their own directives in this regard. This paves the way for a more comprehensive study on the connection of poverty to underdevelopment from spiritual perspective.

\section{Conclusion}

The purpose of this study was to explore the progressive Pentecostal conception of development and transformation. It was argued that the development theories, which the West designed for Africa, failed deplorably to clear up the problem of poverty and underdevelopment and guide 
Africa in building strong, independent and self-sustaining economies. In the midst of such crises, a new trend of Pentecostalism emerged. This movement has offered a radically new conception of development that missiologists labelled the 'third approach' to development. This involves spiritual warfare against the evil one and demons, which are considered as the ultimate - and spiritual - cause of poverty and destitution.

This Pentecostal view is in sharp contrast with the classical approach and the post-development theory that understands poverty largely as material (the solution lies in finance, technology and good governance). On the other hand, this spiritually-oriented view connects with the reality of African society, reflects the biblical truth, and demonstrates that the ultimate cause of poverty is fundamentally spiritual and the solution thus similar. In other words, the solution to developmental issues should be mediated by the Holy Spirit, by delivering individuals from destructive forces.

For this reason, recent studies reveal that this progressive movement has been more successful in dealing with the problem of poverty and underdevelopment than the numerous NGOs. However, the critique from this article is that the success is limited to the individualistic level, whereas it does not take into account the deep-lying causes of poverty within the larger socio-economic structure responsible for the impoverishment of masses. These causes stand as strongholds against processes of development and poverty alleviation. Therefore, for as long as the underlying causes of poverty that ravage the African continent are not dealt with comprehensively, abject poverty is bound to continue. This is the deeper challenge facing progressive Pentecostalists in particular, and the church as the body of Christ in general.

\section{Bibliography}

Amaizo, Y.E. 2012. An alternative African developmentalism: A critique of zero-sum games and palliative economics. Africa Development/ Afrique et Développement. [Online]. Available: http:www.jstor.org/stable/af rdevadev.37.4.117?seq=1\&cid=pdf-reference\#reference_tab_contents [Accessed: 18 February 2017]. 
Anderson, A.H. 2004. An introduction to Pentecostalism: Global charismatic Christianity. New York: Cambridge University Press.

Asamoah-Gyadu, J.K. 2005. African charismatics. Current developments within independent indigenous Pentecostalism in Ghana. Leiden: Brill.

- 2005. Born of water and the Spirit: Pentecostal/charismatic Christianity in Africa. In O.U Kalu, (ed.). African Christianity: An African story. Pretoria: University of Pretoria. 395-404.

- 2004. Mission to 'set the captives free': healing, deliverance, and generational curses in Ghanaian Pentecostalism. International review of mission. International Review of Mission. [Online]. Available: http://onlinelibrary.wiley.com.nwulib.ac.za/10.1002/(ISSN)1758-6631. [Accessed: 19 March 2017].

Asante, M.K \& Mazama, A. 2009. Encyclopaedia of African religion. Thousand Oaks, California: SAGE Publications, Inc.

Attanasi, K. \& Yong, A. 2012. Pentecostalism and prosperity. The socioeconomics of the global charismatic movement. New York: Macmillan, Palgrave.

Babatunde, M.A. 2012. Africa's growth and development strategies: A critical review. Africa Development. [Online]. Available: http://www. ajol.info.nwulib.nwu.ac.za/index.php/articlele/view/87488/77170. [Accessed: 18 March 2016].

Berg, E. 2007. Post-development theory in Africa. Peace review. A Journal of social justice. [Online]. Available: http://nwulib.nwu.ac.za/login?url=http:// search.ebscohost.com/login.aspx?direct=true\&db=eoah\&AN=13235849. [Accessed: 6 February 2017].

Bragg, W.G. 1987. From development to transformation. In V. Samuel \& C. Sugden (eds.). The church in response to human need. Grand Rapids, MI: Eerdmans. 21-51.

Burgess, S.M., McGee, G.B. \& Alexander, P.H. eds. 1989. Dictionary of Pentecostal and charismatic movements. Grand Rapids, MI: Regency Reference Library.

Christian, J. 1999. God of the empty-handed: Poverty, power and the kingdom of God. Monrovia, CA: MARC. 
Coetzee, J.K. 2001. Development. Theory, policy and practice. Cape Town: Oxford University Press.

Dembele, D.M. 2012. Africa's developmental impasse: Some perspectives and recommendations. Africa Development. [Online]. Available: http:// www.ajol.info.nwulib.nwu.ac.za/index.php/article/view/87489/77171. [Accessed: 19 March 2016].

Degbe, S K. 2014. Generational Curses' and the 'Four Homs'Illustrating the Shape of the Primal Worldview. In Contemporary African Pentecostal-Charismatic Spirituality. Journal of Pentecostal Theology. [Online]. Available: http://nwulib.nwu.ac.za/login?url=http://search.ebscohost. com/login.aspx?direct=true\&db=e0ah\&AN=32644104.[Accessed: 20 Mars 2017].

Erickson, M.J. 2013, Christian theology, $3^{\text {rd }}$ ed. Grand Rapids, MI, Baker Academic.

Freeman, D. 2012. Pentecostalism and development: churches, NGOs and social change in Africa. Basingstoke: Palgrave Macmillan.

Haynes, J. 2008. Development studies. Cambridge: Polity Press.

Himmelstran, U. 1994. African perspectives on development:

Controversies, dilemmas and openings. Nairobi: St. Martin's Press.

Kakwata, F. 2014. The Pentecostal church in the Congo/30ème communauté: engaging in poverty eradication. Unpublished doctoral dissertation. Stellenbosch: University of Stellenbosch. Available: http:// scholar.sun.ac.za/handle/10019.1/96077. [Accessed: 12 December 2014].

- 2016. A theology of sin related to poverty. In die Skriflig. [Online]. Available: http://dx.doi.org/10.4102/ids.v50i1.2033. [Accessed: 5 January 2017].

Kalu, O. 2008. African Pentecostalism: An introduction. Oxford: Oxford University Press.

- 2010. African Pentecostalism: Global discourses, migrations, exchanges, and connections. Asmara: Africa World Press.

Lindhardt, M. 2015. Pentecostalism in Africa: presence and impact of pneumatic Christianity in postcolonial societies. Leiden: Brill.

Maggay, M. 1994, Transforming society. London: Regnum. 
Martin, Walter, Rische, Jill, Martin and Van Golden, Kurt. 2008. The kingdom of the occult Nashville, Tenn.: Thomas Nelson.

Miller, D.E. 2009. Progressive Pentecostalism: An emergent trend in global Christianity. Journal of Beliefs \& Values. [Online]. Available: http://www-tandfonline-com.nwulib.nwu.ac.za/doi/pdf/10.1080/13617670903371571. [Accessed: 25 March 2016].

Miller, D.E. \& Yamamori, T. 2007. Global Pentecostalism: The new face of Christian social engagement. Berkeley, LA: University of California Press.

Myers, B.L. 2007. Walking with the poor. Principles and practices of transformation development. New York: Orbis book.

- 2015. Progressive Pentecostalism, development, and Christian development NGOs: A challenge and an opportunity. International Bulletin of Missionary Research. [Online] Available: http://www. internationalbulletin.org/issues/2015-03/2015-03-115-myers.html. [Accessed: 25 March 2016].

Okpara, D.C. 2016. Prayers that break curses and spells and release unusual favors and breakthroughs. Better Life Media. [Online]. Available: http://bookzz.org/book/279643/706114. [Accessed: 07 January 2017].

Phillips, R. \& Pittman, R.H. (eds.) 2009. An introduction to community development. New York, NY: Routledge.

Pogge, T.W. 2004. The First UN Millennium Development Goal: A Cause for Celebration. [Online]. Available: http://www.ilo.org/wcmsp5/groups/ public/---dgreports/---stat/documents/publication/wcms_087882.pdf. [Accessed: 3 March 2017].

Rallo, V. 2000. Breaking generational curses \& pulling down strongholds. Colorado: Creation House Press.

Rodney, W. 2012. How Europe underdeveloped Africa. New York, NY: Black Classic Press.

Sachs, J.D. 2005. Investing in development. A practical plan to achieve the Millennium Development Goals. London: Earthscan. 
Samuel, V. \& Sugden, C. 1987. The church in response to human need. Grand Rapids, MI: Eerdmans.

Sen, Amartya. 1999. Development as freedom. Anchor Books: New York.

Singh, A; Gonzalez, E.T. \& Thomson, S.B. 2013. Millennium Development Goals and community initiatives in the Asia Pacific. New Delhi: Springer.

Togarasei, L. 2011. The Pentecostal gospel of prosperity in African context of poverty: An appraisal. Exchange. [Online]. Available: http://booksandjournals.brillonline.com/content/journal/10.1163/157254311x600744 [Accessed: 11 June 2016].

Winter, R.D., Steven, C. \& Hawthorne, S.C. 1999. Perspectives on the world Christian movement. A reader. Third edition. Pasapdona, CA: William Carey Library.

Ziai, A. 2007. Exploring post-development. Theory and practice, problems and perspectives. New York, NY: Routledge. 